\title{
Novel ocular antihypertensive compounds in clinical trials
}

This article was published in the following Dove Press journal:

Clinical Ophthalmology

19 May 2011

Number of times this article has been viewed

\author{
June Chen' \\ Stephen A Runyan' \\ Michael R Robinson ${ }^{2}$ \\ 'Department of Biological Sciences, \\ ${ }^{2}$ Ophthalmology Clinical Research, \\ Allergan, Inc, Irvine, CA, USA
}

Correspondence: June Chen

Department of Biological Sciences,

Allergan, Inc, 2525 Dupont Dr

Irvine, CA 926I2, USA

$\mathrm{Tel}+\mathrm{I} 7 \mathrm{I} 42465939$

Fax + I 7142462223

Email chen_june@allergan.com
Introduction: Glaucoma is a multifactorial disease characterized by progressive optic nerve injury and visual field defects. Elevated intraocular pressure (IOP) is the most widely recognized risk factor for the onset and progression of open-angle glaucoma, and IOP-lowering medications comprise the primary treatment strategy. IOP elevation in glaucoma is associated with diminished or obstructed aqueous humor outflow. Pharmacotherapy reduces IOP by suppressing aqueous inflow and/or increasing aqueous outflow.

Purpose: This review focuses on novel non-FDA approved ocular antihypertensive compounds being investigated for IOP reduction in ocular hypertensive and glaucoma patients in active clinical trials within approximately the past 2 years.

Methods: The mode of IOP reduction, pharmacology, efficacy, and safety of these new agents were assessed. Relevant drug efficacy and safety trials were identified from searches of various scientific literature databases and clinical trial registries. Compounds with no specified drug class, insufficient background information, reformulations, and fixed-combinations of marketed drugs were not considered.

Results: The investigational agents identified comprise those that act on the same targets of established drug classes approved by the FDA (ie, prostaglandin analogs and $\beta$-adrenergic blockers) as well as agents belonging to novel drug classes with unique mechanisms of action. Novel targets and compounds evaluated in clinical trials include an actin polymerization inhibitor (ie, latrunculin), Rho-associated protein kinase inhibitors, adenosine receptor analogs, an angiotensin II type 1 receptor antagonist, cannabinoid receptor agonists, and a serotonin receptor antagonist.

Conclusion: The clinical value of novel compounds for the treatment of glaucoma will depend ultimately on demonstrating favorable efficacy and benefit-to-risk ratios relative to currently approved prostaglandin analogs and $\beta$-blockers and/or having complementary modes of action.

Keywords: intraocular pressure, glaucoma progression, clinical trials, drug development, aqueous humor dynamics, antihypertensive

\section{Introduction}

Glaucoma, characterized by optic nerve head cupping and visual field defects, is a common cause of preventable and irreversible blindness worldwide. It is a group of ocular conditions in which there is diminished or obstructed outflow of aqueous humor from the eye at the iridocorneal angle, leading to progressive damage to the optic nerve and loss of visual function. The disease can be divided into two broad categories, open-angle and angle-closure (closed-angle) glaucoma, based on the appearance of the anterior chamber angle. Open-angle glaucoma has characteristics of an unobstructed 
and normal iridocorneal angle. In angle-closure glaucoma, the anterior chamber angle is occluded by the peripheral iris. The open-angle glaucomas range from normal-tension glaucoma (NTG; intraocular pressure [IOP] is normal and typically $10-21 \mathrm{~mm} \mathrm{Hg}$ ) to primary (or chronic) open-angle glaucoma (POAG) with elevated IOP., ${ }^{1,2}$

Aqueous humor is produced by the ciliary body epithelium and exits the anterior chamber by two main outflow pathways, trabecular (conventional) and uveoscleral (unconventional). Flow in the trabecular pathway is through the trabecular meshwork into Schlemm's canal and aqueous veins, whereas the uveoscleral pathway is through the ciliary muscle and downstream choroid, sclera, and episcleral tissues. ${ }^{3,4}$ The level of IOP is maintained when the rate of aqueous inflow is equal to the rate of aqueous outflow. Studies indicate that a certain level of IOP is an important causative risk factor for the onset and progression of POAG and NTG, therefore treatment is directed at controlling IOP. $^{2,5}$ It is well established that POAG involves reductions in aqueous humor outflow via the trabecular pathway and a cyclical association with increased IOP. ${ }^{6,7}$ However, a role for uveoscleral outflow in glaucoma pathology is unclear and researchers are not in accordance. ${ }^{4,6}$ The complex mechanisms of damage in open-angle glaucoma have been extensively reviewed, and thus will not be discussed herein. ${ }^{3,6,8-11}$

Medical treatment is the first choice of therapy for openangle glaucoma while laser, surgical peripheral iridotomy, or cataract surgery are initial procedures for primary angleclosure glaucoma, followed by medical therapy. These treatments are aimed at lowering IOP since this is important for slowing the disease progression. A meta-analysis of relevant randomized controlled clinical trials in patients with ocular hypertension found that the risk of conversion to glaucoma is decreased by $14 \%$ with each extra $1 \mathrm{~mm} \mathrm{Hg}$ of IOP reduction. ${ }^{12}$ Additionally, early detection and individualized treatment of glaucoma are needed because of its unpredictable progression and inter- and intra-patient variability. ${ }^{13}$ Pharmacotherapy for glaucoma reduces IOP by suppressing aqueous inflow and/or increasing aqueous outflow. Agents that increase aqueous outflow are desirable for the therapy of POAG since the defect associated with this disease results in diminished outflow. However, identification of novel drug targets has been slow in this research area.

In the majority of glaucoma clinical drug trials, reduction of IOP is the primary efficacy endpoint. For new glaucoma drug approvals, the United States Food and Drug
Administration (FDA) differentiates between the indications for IOP-lowering (do not require proof of changes in structural or functional course of the disease) and glaucoma (need to demonstrate effects on the disease process). ${ }^{14}$ A critical feature for new drug approvals by the FDA is the benefit-to-risk ratio that is determined by drug efficacy and health risk assessment from clinical trials in comparison to the benchmark drugs. ${ }^{14}$ Currently, the five FDA established pharmacologic classes of IOP-lowering drugs are $\alpha$-adrenergic agonist (eg, brimonidine); $\beta$-adrenergic blocker (eg, timolol); carbonic anhydrase inhibitor (eg, dorzolamide); cholinergic agonist (eg, pilocarpine, carbachol); and prostaglandin analog (eg, latanoprost, travoprost, bimatoprost).

The aim of this review is to provide information on novel compounds in clinical trials that are being actively developed for the reduction of IOP in ocular hypertensive and glaucoma patients. Although the discussions include the mode of IOP reduction in humans and non-human primates, pharmacology, efficacy, and safety of these new agents, it is with the acknowledgment that available publications may be scarce.

\section{Methods}

The focus of this review is novel ocular antihypertensive compounds that are active in Phases I-III of glaucoma clinical trials within the past two years ending in December 2010. The new compounds comprise those in established and novel drug classes. We also mention selected compounds that were discontinued within the last three years, and emerging trends among the discussed novel targets. Novel drug delivery systems for IOP-lowering agents were also assessed. Excluded compounds are those with no specified drug class, not enough information or interest, reformulations, and fixed-combinations of marketed drugs. It is not the intent of this review to provide an exhaustive list of agents.

Databases used in the searches included Adis ${ }^{\mathrm{TM}} \mathrm{R} \& \mathrm{D}$ Insight (Wolters Kluwer Pharma) accessed via OvidSP ${ }^{\circledR}$, Integrity $^{\mathrm{SM}}$ (Thomson Reuters), BioPharm Insight ${ }^{\mathrm{TM}}$ (Infinata Inc), Citeline ${ }^{\mathrm{TM}}$ TrialTrove, and Clinical Trial Registry (http:// www.clinicaltrials.gov). Other sources included published articles, meeting abstracts, press releases, and company web sites (reported as of year-end 2010). Novel ocular antihypertensive compounds are summarized in tables as follows: established pharmacologic classes (Table 1); novel targets (Table 2); discontinued or no longer in development (Table 3). 
Table I Novel ocular antihypertensive compounds in established pharmacologic classes

\begin{tabular}{llll}
\hline Drug class/Compound & Organization & Highest development phase & Notes \\
\hline $\begin{array}{l}\text { B-Adrenergic blocker } \\
\text { SYL0400I2 }\end{array}$ & Zeltia/Sylentis & PI/II & $\beta_{2}$-adrenergic antagonist - siRNA \\
$\begin{array}{l}\text { Prostaglandin analogs } \\
\text { AR-102; mopidamol }\end{array}$ & Aerie & PII & FP agonist \\
BOL-303259-X; NCX-II6; & NicOx/Bausch and Lomb & PII & Nitric oxide donating PGF 20 \\
PF-03I87207 & & & agonist; NicOx and Bausch and \\
& & PII & $E_{2}$ agonist
\end{tabular}

Abbreviations: siRNA, small interfering RNA.

\section{Novel compounds in drug classes of FDA standards}

An efficacy standard (benchmark) for new IOP-lowering agents is equivalency to one of four FDA approved ophthalmic products: timolol maleate, latanoprost, bimatoprost, or travoprost. ${ }^{14}$ The proposed new agents are compared with these standards for reduction of elevated IOP as primary therapies or as adjunctive therapies to another IOP-lowering drug in a different pharmacologic class. Importantly, the benefits of new proposed drugs should outweigh the health risks.

\section{Timolol}

Timolol (approved in 1978; Merck Frosst) is a $\beta$-adrenergic blocker that served as the "gold-standard" in glaucoma therapy until the introduction of prostaglandin analogs in 1996. $\beta$-adrenergic blockers lower IOP by decreasing aqueous humor production (aqueous inflow suppressants). Only one novel compound that targets $\beta$-adrenergic receptors is currently in glaucoma clinical trials. Sylentis is conducting a Phase I/II study to establish the efficacy and tolerability of topical SYL040012 in patients with ocular hypertension or glaucoma (Trial ID: NCT01227291). SYL040012 is a small interfering RNA (siRNA) that triggers RNA interference (RNAi), an endogenous cellular process in which doublestranded RNA can cause physiological gene silencing in organisms. ${ }^{15}$ SYL040012 may potentially reduce IOP by knockdown of $\beta_{2}$-adrenergic receptors. This new pharmacological approach appears to be promising for glaucoma treatment; however RNAi-based drugs, in general, face potential development obstacles such as targeted delivery, efficacy, selectivity, and safety. ${ }^{16-18}$

\section{Latanoprost, travoprost, bimatoprost}

Latanoprost (approved in 1996; Pfizer) and travoprost (approved in 2001; Alcon) are prostaglandin analogs that act as agonists at prostanoid FP receptors. Bimatoprost (approved in 2001; Allergan) is a synthetic structural prostaglandin analog that mimics the activity of prostaglandin $\mathrm{F}_{2 \alpha}$ ethanolamide, termed prostamide $\mathrm{F}_{2 \alpha}$. These ophthalmic drugs lower IOP in humans by enhancing aqueous outflow, predominately via the uveoscleral pathway with variable increases in outflow facility (trabecular pathway). ${ }^{19}$

Prostaglandins and thromboxanes, collectively referred to as prostanoids, are biologically active metabolic products of arachidonic acid and other essential fatty acids. Prostanoid receptors belong to the cell-surface G protein-coupled structural family. The cloned receptors are classified into five major types, based on their preferential affinity for the endogenous ligands prostaglandin $\mathrm{D}_{2}(\mathrm{DP}), \mathrm{E}_{2}(\mathrm{EP}), \mathrm{F}_{2 \alpha}$ (FP), $\mathrm{I}_{2}(\mathrm{IP})$, and thromboxane $\mathrm{A}_{2}$ (TP) and its endoperoxide precursor $\mathrm{PGH}_{2} \cdot{ }^{20}$

The prostanoid EP receptor has been further divided into subtypes that have generally excitatory $\left(\mathrm{EP}_{1}, \mathrm{EP}_{3}\right)$ or inhibitory $\left(\mathrm{EP}_{2}, \mathrm{EP}_{4}\right)$ actions on cell function. Taprenepag isopropyl/ PF-04217329 is a novel prostanoid $\mathrm{EP}_{2}$ receptor agonist. Although its mechanism of IOP reduction in humans has not been reported, taprenepag may be inferred to enhance uveoscleral outflow. This is based on results of another $\mathrm{EP}_{2}$ receptor agonist, butaprost, that increases uveoscleral outflow in conscious cynomolgus monkeys. ${ }^{21}$ Pfizer has completed a Phase II safety and efficacy clinical trial of taprenepag at escalating, once-daily, topical ophthalmic doses of $0.0025 \%$ to $0.03 \%$ in patients diagnosed with POAG or ocular hypertension (Trial ID: NCT00572455). The results showed that taprenepag was comparable to latanoprost $0.005 \%$ in IOP reduction, but produced an increased rate of treatment-emergent adverse effects of mild to severe photophobia \pm iritis at $0.015 \%$ and higher concentrations. ${ }^{22,23}$ Taprenepag $0.005 \%, 0.02 \%$, and $0.03 \%$ significantly increased corneal thickness compared to baseline in at least one eye. ${ }^{22}$ It is presently unclear whether taprenepag may benefit from formulation improvements and lower doses. 
Only a few non-novel or unspecified prostaglandin agonists are in clinical trials for glaucoma treatment: AR-102 (FP agonist, Aerie Pharmaceuticals, Phase II, Trial ID: NCT00523250) and NCX-116/BOL-303259-X/PF-03187207 (nitric oxide donating prostaglandin $\mathrm{F}_{2 \alpha}$ agonist, NicOx SA and Bausch and Lomb). Two Phase II trials of the latter compound have recently been completed and await publication (Trial ID: NCT00441883 and NCT00595101); an additional randomized single-masked Phase II is currently recruiting subjects (Trial ID: NCT01223378). Aerie Pharmaceuticals discontinued the development of AR-101 (planned Phase I).

\section{Punctal plugs for drug delivery}

Patient adherence to ocular antihypertensive medication is a challenge in clinical practice. Ophthalmic drug delivery systems are among the technological approaches that may be effective for adherence to glaucoma medication. ${ }^{24}$ Drug-eluting punctal plugs that are being investigated as sustained-release drug delivery systems for latanoprost and bimatoprost are now in advanced stages of clinical testing. The Latanoprost Punctal Plug Delivery System (L-PPDS) is an experimental drug-releasing implant designed to provide sustained delivery of latanoprost for the reduction of IOP. QLT Plug Delivery has designed the device to deliver $44 \mu \mathrm{g}$ or $81 \mu \mathrm{g}$ latanoprost continuously over a period of 3 months. A Phase II, randomized, masked, parallel-group study evaluating the device in open-angle glaucoma or ocular hypertensive patients has been completed (Trial ID: NCT00650702) but the results have not yet been published. Additional Phase II trials are now in progress (Trial ID: NCT00967811, NCT01037036, NCT01229982).

An experimental sustained-release punctal plug for the intraocular delivery of bimatoprost is under clinical development by Vistakon Pharmaceuticals. The efficacy and safety of the bimatoprost punctal plug were evaluated in two randomized, double-blind, Phase II studies in open-angle glaucoma or ocular hypertensive patients (Trial ID: NCT00824720 and NCT01016691). The studies have not yet been published, but initial data from one of the trials indicate that the device did not significantly lower IOP as compared with placebo treatment.

\section{Novel targets}

\section{Actin}

Actin is a monomeric protein with an ability to spontaneously polymerize into helical filaments. The actin filaments and other cytoskeletal protein polymers provide eukaryotic cells with mechanical structure, mobility, and contribute to complex cellular activities. ${ }^{25}$ Latrunculins are macrolides from marine sponges that inhibit actin polymerization by sequestering monomeric actin in a highly specific manner. ${ }^{26-29}$ Studies in living non-human primates (cynomolgus monkeys) and human enucleated postmortem eyes show latrunculin B increases trabecular outflow by a novel mechanism of actin cytoskeleton disruption in cells of the conventional pathway. ${ }^{30-33}$ The increases in outflow may involve expansion of the space between the inner wall of Schlemm's canal and the trabecular collagen beams and/or increased openings between inner wall cells. ${ }^{32,33}$

Inspire Pharmaceuticals evaluated INS-115644, a latrunculin B compound, in a Phase I, 3-day, twice-daily, ascending topical ophthalmic dose $(0.005 \%, 0.01 \%, 0.02 \%$, $0.05 \%$ ) clinical trial to evaluate safety, tolerability, and IOPlowering efficacy in patients with ocular hypertension or early POAG (Trial ID: NCT00443924). INS-115644 reduced IOP only at the $0.02 \%$ and $0.05 \%$ doses, producing a maximal 12 hour decrease of $4 \mathrm{~mm} \mathrm{Hg}$ on day 3 in patients treated with the $0.02 \%$ dose, and was generally well tolerated. ${ }^{34}$ Adverse events included mild ocular redness, irritation, and corneal disorder at the two highest doses $(0.02 \%, 0.05 \%)$ of INS-115644. Inspire also noted a transient, clinically insignificant increase in central corneal thickness of $\leq 2.5 \%$.

In preclinical studies, topically applied latrunculin B $0.005 \%$ or $0.01 \%$, twice-daily for 4.5 days, reduced IOP by $2.5-2.7 \mathrm{~mm} \mathrm{Hg}$ (day 1) to $3.2-4.4 \mathrm{~mm} \mathrm{Hg}$ (day 5) and had no overt adverse effects on the corneas of cynomolgus monkeys. ${ }^{35}$ Compared to human subjects, the non-human primates appear to be more responsive to IOP reduction by latrunculin B at low doses under the laboratory study conditions. At a higher single topical dose of $0.02 \%$ (approximately), latrunculin B reduced the IOP of ocular normotensive cynomolgus monkeys by $3 \mathrm{~mm} \mathrm{Hg}$, but had adverse effects of small transient increases in corneal thickness, increases in corneal endothelial permeability, and anterior chamber flare.$^{30}$ In several topically applied animal studies, latrunculin $\mathrm{B}$ was dissolved in a vehicle that contained $25 \%$ dimethyl sulfoxide (DMSO), due to its low aqueous solubility. ${ }^{35}$ Given its effects on the cornea, IOP-lowering efficacy, and relative insolubility, latrunculin B may benefit from administration by novel drug delivery methods. ${ }^{35,36}$

\section{Rho-associated protein kinase}

The Rho family of small guanosine triphosphatases (GTPases) has a central role in cellular processes, particularly those involving actin cytoskeleton assembly, actin-myosin mediated 
Table 2 Novel ocular antihypertensive targets

\begin{tabular}{|c|c|c|c|}
\hline Target/Compound & Organization & Highest development phase & Notes \\
\hline \multicolumn{4}{|l|}{ Actin } \\
\hline Latrunculin B; INS-I I 5644 & Inspire & $\mathrm{PI}$ & Actin cytoskeleton modulator \\
\hline \multicolumn{4}{|l|}{ Adenosine receptor } \\
\hline ATL-313 & Santen & $\mathrm{PI}$ & Adenosine $A_{2 A}$ agonist \\
\hline CF-I0I & Can-Fite & PII & Adenosine $\mathrm{A}_{3}$ agonist; oral tablet \\
\hline INO-8875; PJ-875 & Inotek & $\mathrm{PI} / \mathrm{II}$ & Adenosine $A_{1}$ agonist \\
\hline OPA-6566 & Acucela/Otsuka & $\mathrm{PI}$ & Adenosine $A_{2 A}$ agonist \\
\hline \multicolumn{4}{|l|}{ Cannabinoid receptor } \\
\hline SAD-448 & Novartis & PI & $\mathrm{CB}_{1} / \mathrm{CB}_{2}$ agonist \\
\hline \multicolumn{4}{|c|}{ Corticosteroid I I- $\beta$-dehydrogenase isozyme I } \\
\hline AZD-40I7 & Astra Zeneca & PII & I I $\beta$ HSDI inhibitor; oral tablet \\
\hline HPP-85I & High Point/TransTech Pharma & $\mathrm{PI}$ & II $\beta$ HSDI inhibitor \\
\hline \multicolumn{4}{|l|}{ Rho-kinase } \\
\hline AR-12286 & Aerie & PII & Rho kinase inhibitor \\
\hline INS-II 7548 & Inspire & $\mathrm{PI}$ & Rho kinase inhibitor \\
\hline $\mathrm{K}-\mathrm{II}$ & Kowa & PII & Rho kinase inhibitor \\
\hline Y-39983; SNJ-I656; RKI-983 & Senju/Novartis & PII & Rho kinase inhibitor \\
\hline \multicolumn{4}{|l|}{ Serotonin receptor } \\
\hline BVT.28949 & Biovitrum & PII & $\begin{array}{l}5-\mathrm{HT}_{2 \mathrm{~A}} \text { antagonist; no development } \\
\text { since } 2008\end{array}$ \\
\hline
\end{tabular}

Abbreviation: HSDI, hydroxysteroid dehydrogenase I.

cell contraction and motility. ${ }^{37,38}$ ROCK (Rho-associated coiled coil-forming protein kinase) is a downstream effector of Rho in the Rho-dependent signal transduction pathway. ${ }^{37,39}$ Thus, specific inhibitors of ROCK that modulate changes in the actin cytoskeleton and cellular motility of the trabecular meshwork, Schlemm's canal, and ciliary muscle may comprise a potential new class of ocular hypotensive drugs that enhance aqueous drainage. ${ }^{40-43}$ ROCK inhibitors may lower resistance to aqueous outflow by activities that include decreasing myosin light-chain phosphorylation, which leads to cellular relaxation in human trabecular meshwork and Schlemm's canal cells. ${ }^{44,45}$ Finding inhibitors that are selective for ROCK is a major challenge because different protein kinases have structurally similar active binding sites yet regulate diverse signaling pathways. ${ }^{46,47}$ Consequently, it may be difficult to attribute the effects of even relatively selective ROCK inhibitors to ROCK specifically and not to other kinases. ${ }^{39,42,48}$ The safety profile of this class of compounds is influenced by its selectivity for inhibiting ROCK as well as any effects on relevant ocular tissues, such as changes in accommodation, pupil diameter, or hyperemia. ${ }^{41,49}$

ROCK inhibitors that are currently in clinical trials for glaucoma or ocular hypertension include AR-12286 (Phase II, Aerie Pharmaceuticals) and K-115 (Phase II, Kowa Pharmaceutical). Other ROCK inhibitors Y-39983/SNJ-1656/ RKI-983 (Phase II, Senju and Novartis Pharmaceuticals) and

Table 3 Ocular antihypertensive compounds discontinued or no longer in development

\begin{tabular}{|c|c|c|c|}
\hline Compound & Organization & Highest development phase & Notes \\
\hline Anecortave acetate & Alcon & PII; discontinued & $\begin{array}{l}\text { Cortisene devoid of glucocorticoid activity; } \\
\text { anterior juxtascleral depot injection in the } \\
\text { sub-Tenon's space to reduce IOP in patients } \\
\text { with glaucoma }\end{array}$ \\
\hline AR-IOI & Aerie & Planned PI, never initiated & Prostaglandin agonist \\
\hline DE-104 & Santen/Ube & PII; discontinued & $\begin{array}{l}\text { Rho-kinase Inhibitor; failed to meet } \mathrm{I}^{\circ} \text { endpoint } \\
\text { in } \mathrm{PI} / \mathrm{II} \text { trial }\end{array}$ \\
\hline $\begin{array}{l}\text { NCX-I I6; } \\
\text { PF-03 I87207 }\end{array}$ & Pfizer/NicOx & PIII; discontinued (Pfizer) & $\begin{array}{l}\text { Nitric oxide donating } \text { PGF }_{2 \alpha} \text { agonist; did not meet } \\
I^{\circ} \text { endpoint; Pfizer terminated PIII development } \\
\text { in 2008; NicOx reacquired rights to NCX-I I } 6 \text { in } \\
2009 \text {; see BOL-303259-X in Table I }\end{array}$ \\
\hline $\begin{array}{l}\text { Olmesartan medoxomil; } \\
\text { DE-092; CS-088 }\end{array}$ & Santen/Daiichi Sankyo & PII; discontinued & $\begin{array}{l}\text { Angiotensin II AT, antagonist; did not } \\
\text { demonstrate clear dose response }\end{array}$ \\
\hline
\end{tabular}

Abbreviation: IOP, intraocular pressure. 
INS-117548 (Phase I, Inspire Pharmaceuticals) are still under development, but have encountered efficacy and tolerability challenges. DE-104 (Phase I/II, Santen Pharmaceuticals and Ube Industries) development was discontinued in late 2010 after its trial failed to meet the primary endpoint.

AR-12286 originated from a 6-aminoisoquinoline amide series and exhibits nanomolar potency against ROCK. ${ }^{50}$ Aerie Pharmaceuticals reported that AR-12286 is more selective than a competing ROCK inhibitor Y-39983/SNJ-1656/ RKI-983 (Senju and Novartis) with activity at 5 versus 25 of the off-target kinases that were tested. ${ }^{51}$ Topical AR-12286 $0.6 \%$ lowered IOP in ocular normotensive non-human primates primarily by increasing trabecular outflow. ${ }^{52}$ The company conducted a Phase IIa safety and efficacy clinical trial of AR-12286 at topical ophthalmic doses of $0.05 \%$, $0.1 \%$, and $0.25 \%$, once-daily followed by twice-daily over 3 weeks, in patients with ocular hypertension or glaucoma (Trial ID: NCT00902200). AR-12286 lowered the IOP by $4.4 \mathrm{~mm} \mathrm{Hg}$ to a maximum of $6.8 \mathrm{~mm} \mathrm{Hg}(28 \%)$ in patients treated with twice-daily $0.25 \%$ AR-12286, and the only adverse effect presented was trace to moderate conjunctival hyperemia. ${ }^{53}$ Aerie completed a Phase IIb, 28-day, safety and efficacy clinical trial of topical AR-12286 0.25\% twice-daily or $0.5 \%$ once-daily versus latanoprost in 2010 (Trial ID: NCT01060579). Although AR-12286 is a relatively selective agent, its long-term tolerability profile and IOP-lowering efficacy in humans are unknown.

$\mathrm{K}-115$, an isoquinolinesulfonamide compound, is a highly selective and potent $\left(\mathrm{IC}_{50}=31 \mathrm{nM}\right)$ Rho-kinase inhibitor. ${ }^{54}$ It is in Phase II clinical development in patients with POAG or ocular hypertension by Kowa Pharmaceuticals (Trial IDs: JapicCTI-090708 and JapicCTI-101015). Preclinical studies in monkeys showed 2.3 to $4.4 \mathrm{~mm} \mathrm{Hg}$ decreases in IOP following topical K-115 0.1\%, 0.2\%, 0.4\% versus a $2.5 \mathrm{~mm} \mathrm{Hg}$ decrease for latanoprost $0.005 \% .{ }^{54}$

Y-39983 (synonym RKI-983) is in Phase II clinical trials with Senju and Novartis Pharmaceuticals. Topical SNJ-1656 (an ophthalmic solution of Y-39983) reduced IOP by $3-4 \mathrm{~mm} \mathrm{Hg}$ after single or repeated instillations $(0.1 \%)$ and elicited trace to mild conjunctival hyperemia $(0.003 \%$ to $0.1 \%$ ) in healthy male volunteers evaluated in a 7-day Phase I clinical trial. ${ }^{55}$ Novartis conducted Phase I/II clinical trials of topical RKI-983, twice-daily at $0.01 \%-0.05 \%$ (7 days) and $0.05 \%, 0.1 \%$ (29 days), versus vehicle and comparator latanoprost, once-daily at $0.005 \%$, in patients with POAG or ocular hypertension (Trial IDs: CRKI983A2101/ NCT00515424; CRKI983A2201/NCT00846989). Results of the latter study showed RKI-983 $0.1 \%$ reduced IOP by
$4.8 \mathrm{~mm} \mathrm{Hg}$ (19.6\%; day 29 average) and had an adverse events profile that included ocular disorders, most commonly mild to severe conjunctival hyperemia, followed by vascular disorders and other affected systems (Novartis Clinical Trial Results Database). Thus, RKI-983 exhibited inferiority in IOP-lowering efficacy and tolerability compared to latanoprost which had an average IOP decrease of $6.7 \mathrm{~mm} \mathrm{Hg}$ $(27.3 \%)$ on day 29 .

Topically applied $0.05 \%$ Y-39983 or SNJ-1656 had similar IOP-lowering efficacies in human volunteers $(2 \mathrm{~mm} \mathrm{Hg})$ and ocular normotensive cynomolgus monkeys $(2.5 \mathrm{~mm} \mathrm{Hg}){ }^{49,55}$ In contrast, Y-39983 achieved substantially larger IOP reductions of 2.5 to $12 \mathrm{~mm} \mathrm{Hg}$ at $0.003 \%$ to $0.05 \%$ in rabbits compared to decreases of 0.4 to $2.5 \mathrm{~mm} \mathrm{Hg}$ in ocular normotensive cynomolgus monkeys over the same dose range. ${ }^{49}$ The dissimilar IOP responses may reflect species differences with respect to anatomy, physiology, pharmacokinetics, or the expression levels of ROCK and ROCK substrates in various ocular tissues. Toxicological studies indicated safety concerns, citing punctate subconjunctival hemorrhage and conjunctival hyperemia in rabbits and cynomolgus monkeys treated four-times daily with Y-39983 $0.03 \%$ or $0.05 \% .{ }^{49}$

INS-1 17548 is another ROCK inhibitor that had efficacy and tolerance concerns following a Phase I safety, tolerability, and ascending dose efficacy clinical trial in patients with early stage glaucoma or ocular hypertension (Trial ID: NCT00767793). Inspire Pharmaceuticals reported that twicedaily INS-117548 produced mild reductions in IOP and some dose-related adverse effects, specifically ocular burning and stinging. The company is evaluating future directions in their glaucoma program.

\section{Adenosine receptor}

Adenosine is an endogenous purine nucleoside that modulates physiological and pathophysiological processes by activating the $\mathrm{G}$ protein-coupled adenosine receptors..$^{20,56,57}$ The four adenosine receptor subtypes that have been cloned are $\mathrm{A}_{1}, \mathrm{~A}_{2 \mathrm{~A}}, \mathrm{~A}_{2 \mathrm{~B}}$, and $\mathrm{A}_{3}$. Discerning which receptors are associated with IOP modulations has been difficult, since many of the earlier adenosine ligands evaluated are not highly selective for a particular receptor subtype. For example, adenosine agonist R-PIA has binding affinities $\left(\mathrm{K}_{\mathrm{i}}\right)$ at human adenosine receptor subtypes of $2 \mathrm{nM}\left(\mathrm{A}_{1}\right), 16 \mathrm{nM}\left(\mathrm{A}_{3}\right), 860 \mathrm{nM}\left(\mathrm{A}_{2 \mathrm{~A}}\right)$, and 3,800-33,700 $\mathrm{nM}\left(\mathrm{A}_{2 \mathrm{~B}}\right){ }^{56}$ It produced early dose-related IOP increases that were followed by later IOP decreases, an increase in total outflow facility (trabecular pathway), and modest changes in aqueous humor flow in conscious ocular normotensive cynomolgus monkeys. ${ }^{58}$ The mechanisms by 
which adenosine receptor agonists increase conventional outflow have been hypothesized to involve shrinkage of cell volume and remodeling of the extracellular matrix following secretion of matrix metalloproteinases in human trabecular meshwork cells. ${ }^{59-62}$ Adenosine $\mathrm{A}_{3}$ antagonists may potentially influence aqueous humor formation by preventing adenosine-induced activation of chloride channels in human nonpigmented ciliary epithelial cells..$^{63,64}$ Therefore, adenosine $A_{1}, A_{2 A}, A_{3}$ receptor agonists and $A_{3}$ receptor antagonists have all been considered for IOP reduction.

The adenosine analogs that are currently in glaucoma clinical trials include INO-8875/PJ-875 (A $\mathrm{A}_{1}$ agonist, Phase I/II, Inotek Pharmaceuticals), OPA-6566 ( $\mathrm{A}_{2 \mathrm{~A}}$ agonist, Phase I planned in 2011, Acucela and Otsuka Pharmaceutical), ATL-313 ( $\mathrm{A}_{2 \mathrm{~A}}$ agonist, Phase I planned in 2011, Santen Pharmaceutical), and CF-101 ( $\mathrm{A}_{3}$ agonist, Phase II, Can-Fite BioPharma). Compounds that target the $\mathrm{A}_{3}$ receptor as antagonists instead of agonists are in the preclinical stage.

INO-8875 (synonym PJ-875) is a potent agonist at $\mathrm{A}_{1}$ receptors $\left(\mathrm{K}_{\mathrm{i}}=0.97 \mathrm{nM}\right)$ that was shown to increase the facility of trabecular outflow in a perfused anterior segment model using porcine isolated corneo-scleral shells. ${ }^{65,66}$ Information regarding its activity at other receptors and effects on aqueous humor dynamics in living non-human primates has not been provided. Inotek Pharmaceuticals is conducting a Phase I/II dose-escalation clinical trial to evaluate the tolerability, safety, and efficacy of twice-daily topical INO-8875 in patients with ocular hypertension or POAG (Trial ID: NCT01123785). The company did not release details of an earlier Phase I/II single ascending ocular dose study, but reported that topical INO-8875 reduced IOP at the two highest doses tested. Preclinical studies indicated statistically significant IOP decreases in ocular normotensive cynomolgus monkeys and pigmented rabbits given single topical INO-8875 doses of 10-1000 $\mu \mathrm{g}$ and $5-150 \mu \mathrm{g}$, respectively, with maximum IOP reductions of $20 \%-25 \%$ at $1-2$ hours post-dose. ${ }^{66}$

The two adenosine $A_{2 A}$ receptor agonists that have advanced to Phase I clinical trials with plans to start in 2011 are OPA-6566 (Acucela and Otsuka Pharmaceutical) and ATL-313 (Santen Pharmaceutical). $A_{2 \mathrm{~A}}$ receptors couple through $G$ proteins to stimulate adenylyl cyclase, mediate vasodilatation, and may be down-regulated after chronic exposure to agonist. ${ }^{67,68}$ Therefore, conjunctival hyperemia and some loss of effectiveness over time are among the potential liabilities of topically administered $\mathrm{A}_{2 \mathrm{~A}}$ agonists.

CF-101 (generic name IB-MECA) is categorized by Can-Fite BioPharma as an $\mathrm{A}_{3}$ agonist. However, it has potent affinity $\left(\mathrm{K}_{\mathrm{i}}\right)$ at human adenosine $\mathrm{A}_{3}(1.2-1.8 \mathrm{nM})$ as well as
$\mathrm{A}_{1}(3.7-51 \mathrm{nM})$ receptors relative to $\mathrm{A}_{2 \mathrm{~A}}(2,500-2,900 \mathrm{nM})$ and $\mathrm{A}_{2 \mathrm{~B}}(54,000 \mathrm{nM})$ receptors. ${ }^{56,69}$ Can-Fite is conducting a Phase II safety and efficacy clinical trial of orally administered CF-101 in patients with elevated IOP or POAG (Trial ID: NCT01033422). The rationale for conducting this study is based on an unexpected finding of a $1.1 \mathrm{~mm} \mathrm{Hg} \mathrm{IOP}$ decrease at week 12 during the safety assessment of orally administered CF-101 in a Phase II dry eye trial. ${ }^{70}$

Antagonists that target $\mathrm{A}_{3}$ receptors have also been proposed for IOP reduction, but drug candidates have not yet progressed to the clinical trials phase. ${ }^{69,71}$ One such compound is OT-7999, a potent and selective $\mathrm{A}_{3}$ antagonist $\left(\mathrm{K}_{\mathrm{i}}=0.61 \mathrm{nM}\right)$ with $\mathrm{K}_{\mathrm{i}}>10,000 \mathrm{nM}$ at the $\mathrm{A}_{1}, \mathrm{~A}_{2 \mathrm{~A}}$, and $\mathrm{A}_{2 \mathrm{~B}}$ receptors. ${ }^{72}$ OT-7999, at a single topical $1 \%$ dose, decreased IOP by $1.6 \mathrm{~mm} \mathrm{Hg}$ in conscious male cynomolgus monkeys and was well tolerated. ${ }^{72}$

\section{Angiotensin II receptor}

Angiotensin II is an endogenous peptide that elicits potent vasoconstriction and serves to modulate systemic blood pressure by activating the $\mathrm{G}$ protein-coupled angiotensin II receptor, type $\left.\mathrm{I}\left(\mathrm{AT}_{1}\right)\right)^{20,73,74}$ Olmesartan medoxomil is an orally administered $\mathrm{AT}_{1}$ receptor antagonist marketed for the treatment of systemic hypertension. In the eye, however, pharmacological effects of $\mathrm{AT}_{1}$ receptor antagonists on human cells and tissues have not been well characterized nor functionally correlated to IOP changes. AT 1 antagonists may inhibit angiotensin II activities such as myosin light-chain phosphorylation in human trabecular meshwork cells. ${ }^{75}$ Losartan, an $\mathrm{AT}_{1}$ antagonist, was shown to block angiotensin II activation of calcium sensitive large conductance potassium channels and cell volume loss in cultured cells of human nonpigmented ciliary epithelium. ${ }^{76}$

Topical olmesartan (synonyms DE-092, CS-088) was in early Phase II glaucoma clinical trials until late 2008, when Santen Pharmaceutical and Daiichi Sankyo Co terminated the study. Santen announced that DE-092 produced some IOP reductions; however the efficacy was insufficient with no clear dose-reponse relationship. The preclinical results support the clinical findings. Unilateral laser-induced ocular hypertensive cynomolgus monkeys treated with twice-daily topical CS-088 at a $2 \%$ or $4 \%$ dose had IOP reductions of $5.3 \mathrm{~mm} \mathrm{Hg} \mathrm{(15 \% )}$ and $6.9 \mathrm{~mm} \mathrm{Hg} \mathrm{(20 \% ),} \mathrm{respectively,} \mathrm{on} \mathrm{day} 5$ of the study. ${ }^{77}$ Another study showed small reductions in outflow facility and increases in uveoscleral outflow of cynomolgus monkeys given topical twice-daily olmesartan $4 \%{ }^{78}$ The small IOP reductions were explained by opposing effects via the trabecular and uveoscleral outflow pathways. 


\section{Cannabinoid receptor}

Endocannabinoids and the psychoactive $\Delta^{9}$-tetrahydrocannabinol ( $\Delta^{9}$-THC), derived from Cannabis sativa (marijuana), are among the ligands that activate $\mathrm{G}$ protein-coupled cannabinoid receptors. ${ }^{79} \mathrm{CB}_{1}$ and $\mathrm{CB}_{2}$ subtypes are two cannabinoid receptors that have been cloned and characterized. ${ }^{20}$ The medicinal uses of cannabis, including treatment for glaucoma via systemic exposure, have been known since ancient times. ${ }^{79-81}$ More recently, local mechanisms of IOP reduction were studied using WIN 55212-2, a potent synthetic cannabinoid $\mathrm{CB}_{1}$ and $\mathrm{CB}_{2}$ receptor agonist. ${ }^{80,82,83}$ In ocular normotensive cynomolgus monkeys, topically administered WIN 55212-2 0.5\% lowered IOP by $3.4 \mathrm{~mm} \mathrm{Hg} \mathrm{(19 \% )} \mathrm{and}$ reduced aqueous humor flow, but did not change the tonographic outflow facility. ${ }^{82}$ Cannabinoid agonists can activate multiple signal transduction cascades that lead to activities such as relaxation and antimigration in human ocular tissues, but the functional associations with IOP modulation remain unclear. ${ }^{84-86}$

Novartis Pharmaceuticals conducted a Phase I clinical trial in 2007 on SAD-448, a $\mathrm{CB}_{1}$ and $\mathrm{CB}_{2}$ receptor agonist. ${ }^{87}$ The tolerability, safety, and efficacy of topical SAD-448 0.02\% as a single drop and multiple drops (4 at 1 hour intervals) were assessed in subjects with ocular hypertension (Trial ID: NCT00503360). SAD-448 reduced IOP by $2.3-2.4 \mathrm{~mm} \mathrm{Hg}$, which was not different from placebo, while the active comparator latanoprost $0.005 \%$ produced a $3.5 \mathrm{~mm} \mathrm{Hg}$ decrease (Novartis Clinical Trial Results Database). No further development has been reported since 2008 .

Although not categorized as a $\mathrm{CB}_{1} / \mathrm{CB}_{2}$ agonist, palmitoylethanolamide (PEA) is an endogenous fatty acid ethanolamide that acts at cannabinoid-like receptors. ${ }^{20}$ The University of Catania (Italy) has evaluated Visimast ${ }^{\mathbb{}}$ (PEA) as an adjunctive oral therapy in POAG patients under topical antihypertensive drug treatment (Trial ID: UMIN000002833). The mean IOP reductions were greater by $2.4-3.4 \mathrm{~mm} \mathrm{Hg}$ in patients given oral PEA $300 \mathrm{mg}$, twice-daily, compared to placebo on days 30 and $60 .^{88}$

\section{Serotonin receptor}

Serotonin (5-hydroxytryptamine, 5-HT) is a biogenic monoamine neurotransmitter that activates a large family of receptors in the $\mathrm{G}$ protein-coupled (5-HT $\mathrm{HA}_{1 \mathrm{~B}, 1 \mathrm{D}, 1 \mathrm{E}, 1 \mathrm{~F}}$ $\left.5-\mathrm{HT}_{2 \mathrm{~A}, 2 \mathrm{~B}, 2 \mathrm{C}}, 5-\mathrm{HT}_{4}, 5-\mathrm{HT}_{5 \mathrm{~A}, 5 \mathrm{~B}}, 5-\mathrm{HT}_{6}, 5-\mathrm{HT}_{7}\right)$ and ligandgated ion channel $\left(5-\mathrm{HT}_{3}\right)$ structural families. ${ }^{20,89} \mathrm{~A}$ few cases of elevated IOP or angle-closure glaucoma have been reported in patients treated with selective serotonin reuptake inhibitors (SSRIs) which increase serotonin neurotransmission, suggesting a potential role for antagonists. ${ }^{90}$ Interestingly, preclinical studies indicated that topically applied 5- $\mathrm{HT}_{2}$ agonists, but not 5- $\mathrm{HT}_{1 \mathrm{~A}}$ agonists or 5- $\mathrm{HT}_{2}$ antagonists, effectively reduced the IOP of ocular normotensive and hypertensive cynomolgus monkeys. ${ }^{91,92}$ A 5-HT $2 \mathrm{~A}, 2 \mathrm{~B}, 2 \mathrm{C}$ receptor partial agonist, $\mathrm{R}$-DOI ( $R$-2,5-dimethoxy-4-iodoamphetamine), lowered IOP of cynomolgus monkeys primarily by a mechanism of increasing uveoscleral outflow, but also caused a small increase in aqueous humor formation. ${ }^{92,93} \mathrm{R}-\mathrm{DOI}$ is a LSD (lysergic acid diethylamide)-like hallucinogen whose psychedelic effects are mediated by the $5-\mathrm{HT}_{2 \mathrm{~A}}$ receptor. ${ }^{89,94}$ Studies indicate that serotonin receptor regulation and signal transduction pathways are diverse and complex. ${ }^{89}$ For example, multiple scaffolding proteins and kinases regulate $5-\mathrm{HT}_{2 \mathrm{~A}}$ receptor function, and both agonists and some antagonists induce receptor down-regulation. ${ }^{94,95}$ Therefore, $5-\mathrm{HT}_{2}$ agonists and antagonists have been proposed for IOP reduction. Some potential development obstacles pertaining to efficacy and adverse effects may be a lack of selectivity for the targeted serotonin receptor subtype and activity at non-serotonin receptors.

Swedish Orphan Biovitrum (Biovitrum) completed an exploratory Phase IIa clinical trial in 2008 on BVT.28949, a $5-\mathrm{HT}_{2 \mathrm{~A}}$ receptor antagonist, in glaucoma or ocular hypertensive patients (TrialTroveID: 070502). BVT.28949 (2 or $7 \mathrm{mg} / \mathrm{ml}$ dose) twice-daily reduced IOP by $2.3 \mathrm{~mm} \mathrm{Hg}$ (10\%) after 4 weeks of treatment. Similarly, preclinical results of topical once-daily BVT.28949 $(10 \mathrm{mM}$ or $50 \mathrm{mM}$ dose at $10 \mu$ volume) showed $1-3 \mathrm{~mm} \mathrm{Hg}$ reductions in IOP of ocular normotensive cynomolgus monkeys. ${ }^{96}$ No further development of this compound has been reported.

\section{Summary}

Medical treatments to lower IOP are important for slowing the progression of glaucoma and delaying vision loss. New technological approaches for treating elevated IOP include siRNA and drug-eluting punctal plugs. The recent focus of new medical treatments for ocular hypertension and glaucoma is on novel targets for increasing aqueous humor outflow, particularly via the trabecular pathway. For first-line medical therapy, the new drug entities are compared to the benchmark standards and must demonstrate equivalent or superior safety and efficacy, as related to IOP reduction. The novel compounds evaluated in clinical trials include an actin polymerization inhibitor, Rho-associated protein kinase inhibitors, adenosine receptor agonists, an angiotensin II type 1 receptor antagonist, cannabinoid receptor agonists, and a serotonin receptor antagonist. Results of the clinical trials to 
date suggest that these agents may need improvements to meet the safety and efficacy endpoints. Approval for adjunctive therapy is an alternative for compounds that do not achieve first-line status. Promising compounds are efficacious, exhibit favorable benefit-to-risk ratios, and have novel modes of action that are complementary to the marketed glaucoma medications. Although this review focused on IOP reduction and safety, compounds possessing properties that address the underlying disease process are highly desirable.

\section{Acknowledgment}

We thank Sean Bullock in the corporate information center for advice on the database searches.

\section{Disclosure}

The authors report no conflicts of interest in this work.

\section{References}

1. Desai PV, Caprioli J. The treatment of normal-tension glaucoma. Prog Brain Res. 2008;173:195-210.

2. Shields MB. Normal-tension glaucoma: is it different from primary open-angle glaucoma? Curr Opin Ophthalmol. 2008;19(2):85-88.

3. Fautsch MP, Johnson DH. Aqueous humor outflow: what do we know? Where will it lead us? Invest Ophthalmol Vis Sci. 2006;47(10): 4181-4187.

4. Alm A, Nilsson SF. Uveoscleral outflow - a review. Exp Eye Res. 2009;88(4):760-768.

5. Bahrami H. Causal inference in primary open angle glaucoma: specific discussion on intraocular pressure. Ophthalmic Epidemiol. 2006;13(4): 283-289.

6. Gabelt BT, Kaufman PL. Changes in aqueous humor dynamics with age and glaucoma. Prog Retin Eye Res. 2005;24(5):612-637.

7. Johnson M. What controls aqueous humour outflow resistance? Exp Eye Res. 2006;82(4):545-557.

8. Pache M, Flammer J. A sick eye in a sick body? Systemic findings in patients with primary open-angle glaucoma. Surv Ophthalmol. 2006 51(3):179-212.

9. Tektas OY, Lütjen-Drecoll E. Structural changes of the trabecular meshwork in different kinds of glaucoma. Exp Eye Res. 2009; 88(4):769-775.

10. Kwon YH, Fingert JH, Kuehn MH, Alward WL. Primary open-angle glaucoma. N Engl J Med. 2009;360(11):1113-1124.

11. Wierzbowska J, Robaszkiewicz J, Figurska M, Stankiewicz A. Future possibilities in glaucoma therapy. Med Sci Monit. 2010;16(11): RA252-RA259.

12. Peeters A, Webers CA, Prins MH, Zeegers MP, Hendrikse F, Schouten JS. Quantifying the effect of intraocular pressure reduction on the occurrence of glaucoma. Acta Ophthalmol. 2010;88(1):5-11.

13. Susanna R Jr. Unpredictability of glaucoma progression. Curr Med Res Opin. 2009;25(9):2167-2177.

14. Weinreb RN, Kaufman PL. The glaucoma research community and FDA look to the future: a report from the NEI/FDA CDER Glaucoma Clinical Trial Design and Endpoints Symposium. Invest Ophthalmol Vis Sci. 2009;50(4):1497-1505.

15. Fire A, Xu S, Montgomery MK, Kostas SA, Driver SE, Mello CC Potent and specific genetic interference by double-stranded RNA in Caenorhabditis elegans. Nature. 1998;391(6669):806-811.

16. Qiu S, Adema CM, Lane T. A computational study of off-target effects of RNA interference. Nucleic Acids Res. 2005;33(6):1834-1847.
17. Castanotto D, Rossi JJ. The promises and pitfalls of RNA-interferencebased therapeutics. Nature. 2009;457(7228):426-433.

18. Wang J, Lu Z, Wientjes MG, Au JL. Delivery of siRNA therapeutics: barriers and carriers. AAPS J. 2010;12(4):492-503.

19. Lim KS, Nau CB, O’Byrne MM, et al. Mechanism of action of bimatoprost, latanoprost, and travoprost in healthy subjects. A crossover study. Ophthalmology. 2008;115(5):790-795.

20. Alexander SPH, Mathie A, Peters JA. Guide to Receptors and Channels (GRAC), 4th edn. Br J Pharmacol. 2009;(158 Suppl 1):S1-S254.

21. Nilsson SF, Drecoll E, Lütjen-Drecoll E, et al. The prostanoid $\mathrm{EP}_{2}$ receptor agonist butaprost increases uveoscleral outflow in the cynomolgus monkey. Invest Ophthalmol Vis Sci. 2006;47(9): 4042-4049.

22. Schachar RA, Raber S, Courtney R, Zhang M, Bosworth C. Doseescalating, double-masked, vehicle-controlled trial of the IOP-reducing effect of the EP 2 agonist PF-04217329. Invest Ophthalmol Vis Sci. 2010;51: Association for Research in Vision and Ophtahlmology (ARVO) E-Abstract 175

23. Schachar RA, Raber S, Zhang MH, Bosworth CF. A randomized, multicenter clinical trial of the IOP-reducing effect of the $\mathrm{EP}_{2}$ agonist taprenepag isopropyl (PF-04217329). American Academy of Ophthalmology. 2010;Abstract PO373.

24. Kowing D, Messer D, Slagle S, Wasik A; V-POAG Study Group. Programs to optimize adherence in glaucoma. Optometry. 2010;81(7):339-350.

25. Pollard TD, Cooper JA. Actin, a central player in cell shape and movement Science. 2009;326(5957):1208-1212.

26. Groweiss A, Shmueli U, Kashman Y. Marine toxins of Latrunculia magnifica. J Org Chem. 1983;48:3512-3516.

27. Coué M, Brenner SL, Spector I, Korn ED. Inhibition of actin polymerization by latrunculin A. FEBS Lett. 1987;213(2):316-318.

28. Spector I, Braet F, Shochet NR, Bubb MR. New anti-actin drugs in the study of the organization and function of the actin cytoskeleton. Microsc Res Tech. 1999;47(1):18-37.

29. Wakatsuki T, Schwab B, Thompson NC, Elson EL. Effects of cytochalasin D and latrunculin B on mechanical properties of cells. J Cell Sci. 2001;114(Pt 5):1025-1036.

30. Peterson JA, Tian B, McLaren JW, Hubbard WC, Geiger B, Kaufman PL. Latrunculins' effects on intraocular pressure, aqueous humor flow, and corneal endothelium. Invest Ophthalmol Vis Sci. 2000; 41(7):1749-1758.

31. Okka M, Tian B, Kaufman PL. Effect of low-dose latrunculin B on anterior segment physiologic features in the monkey eye. Arch Ophthalmol. 2004;122(10):1482-1488. Comment in: Arch Ophthalmol. 2005 Oct;123(10):1456-1457; author reply 1457.

32. Sabanay I, Tian B, Gabelt BT, Geiger B, Kaufman PL. Latrunculin B effects on trabecular meshwork and corneal endothelial morphology in monkeys. Exp Eye Res. 2006;82(2):236-246.

33. Ethier CR, Read AT, Chan DW. Effects of latrunculin-B on outflow facility and trabecular meshwork structure in human eyes. Invest Ophthalmol Vis Sci. 2006;47(5):1991-1998.

34. Ritch R, Schiewe M, Zink RC, et al. Latrunculin B (INS115644) reduces intraocular pressure (IOP) in ocular hypertension (OHT) and primary open angle glaucoma (POAG). Invest Ophthalmol Vis Sci. 2010;51: ARVO E-Abstract and Poster 6432.

35. Okka M, Tian B, Kaufman PL. Effects of latrunculin B on outflow facility, intraocular pressure, corneal thickness, and miotic and accommodative responses to pilocarpine in monkeys. Trans Am Ophthalmol Soc. 2004;102:251-259.

36. Tian B, Gabelt BT, Geiger B, Kaufman PL. The role of the actomyosin system in regulating trabecular fluid outflow. Exp Eye Res. 2009;88(4):713-717.

37. Riento K, Ridley AJ. Rocks: multifunctional kinases in cell behaviour. Nat Rev Mol Cell Biol. 2003;4(6):446-456.

38. Hall A. Rho GTPases and the control of cell behaviour. Biochem Soc Trans. 2005;33(Pt 5):891-895.

39. Olson MF. Applications for ROCK kinase inhibition. Curr Opin Cell Biol. 2008;20(2):242-248 
40. Fukiage C, Mizutani K, Kawamoto Y, Azuma M, Shearer TR. Involvement of phosphorylation of myosin phosphatase by ROCK in trabecular meshwork and ciliary muscle contraction. Biochem Biophys Res Commun. 2001;288(2):296-300.

41. Nakajima E, Nakajima T, Minagawa Y, Shearer TR, Azuma M. Contribution of ROCK in contraction of trabecular meshwork: proposed mechanism for regulating aqueous outflow in monkey and human eyes. J Pharm Sci. 2005;94(4):701-708.

42. Rao VP, Epstein DL. Rho GTPase/Rho kinase inhibition as a novel target for the treatment of glaucoma. Bio Drugs. 2007;21(3):167-177.

43. Inoue $T$, Pecen $P$, Maddala $R$, et al. Characterization of cytoskeletonenriched protein fraction of the trabecular meshwork and ciliary muscle cells. Invest Ophthalmol Vis Sci. 2010;51(12):6461-6471.

44. Rao PV, Deng PF, Kumar J, Epstein DL. Modulation of aqueous humor outflow facility by the Rho kinase-specific inhibitor Y-27632. Invest Ophthalmol Vis Sci. 2001;42(5):1029-1037. Erratum in: Invest Ophthalmol Vis Sci. 2001;42(8):1690.

45. Koga T, Koga T, Awai M, Tsutsui J, Yue BY, Tanihara H. Rho-associated protein kinase inhibitor, Y-27632, induces alterations in adhesion, contraction and motility in cultured human trabecular meshwork cells. Exp Eye Res. 2006;82(3):362-370.

46. Mueller BK, Mack H, Teusch N. Rho kinase, a promising drug target for neurological disorders. Nat Rev Drug Discov. 2005;4(5):387-398.

47. Jacobs M, Hayakawa K, Swenson L, et al. The structure of dimeric ROCK I reveals the mechanism for ligand selectivity. $J$ Biol Chem. 2006;281(1):260-268.

48. Tamura M, Nakao H, Yoshizaki H, et al. Development of specific Rhokinase inhibitors and their clinical application. Biochim Biophys Acta. 2005;1754(1-2):245-252.

49. Tokushige $\mathrm{H}$, Inatani $\mathrm{M}$, Nemoto $\mathrm{S}$, et al. Effects of topical administration of Y-39983, a selective rho-associated protein kinase inhibitor, on ocular tissues in rabbits and monkeys. Invest Ophthalmol Vis Sci. 2007;48(7):3216-3222.

50. DeLong MA, Sturdivant JM, Royalty SM, et al. Discovery and in vitro SAR of AR-12286, a potent kinase inhibitor for the treatment of glaucoma. From Abstracts of Papers, 240th American Chemical Society National Meeting, Boston, MA, US, August 22-26, 2010 (2010), MEDI-307. Database: CAPLUS.

51. McCallister E. RhoKing glaucoma. BioCentury, The Bernstein Report on BioBusiness. 2009 Oct 26;Page A8. http://www.biocentury.com.

52. Wang R-F, Serle JB, Kopczynski C. Effect of $0.6 \%$ AR- 12286 on aqueous humor dynamics in 6 normotensive monkey eyes. Invest Ophthalmol Vis Sci. 2009;50:ARVO E-Abstract 1465.

53. Williams RD, Novack GD, van Haarlem T, Kopczynski C, and AR-12286 Phase 2a Study Group. Ocular hypotensive efficacy and safety of the Rho kinase inhibitor AR-12286 in patients with elevated intraocular pressure. Invest Ophthalmol Vis Sci. 2010;51: ARVO E-Abstract 1633.

54. Mizuno K, Koide T, Fujieda Y, et al. Ocular hypotensive and neuroprotective effects of K-115, a novel Rho-kinase inhibitor. Invest Ophthalmol Vis Sci. 2007;48:ARVO E-Abstract 4805.

55. Tanihara $\mathrm{H}$, Inatani $\mathrm{M}$, Honjo $\mathrm{M}$, Tokushige $\mathrm{H}$, Azuma J, Araie $\mathrm{M}$. Intraocular pressure-lowering effects and safety of topical administration of a selective ROCK inhibitor, SNJ-1656, in healthy volunteers. Arch Ophthalmol. 2008;126(3):309-315.

56. Fredholm BB, Ijzerman AP, Jacobson KA, Klotz KN, Linden J. International Union of Pharmacology. XXV. Nomenclature and classification of adenosine receptors. Pharmacol Rev. 2001;53(4):527-552.

57. Fredholm BB. Adenosine receptors as drug targets. Exp Cell Res. 2010;316(8):1284-1288.

58. Tian B, Gabelt BT, Crosson CE, Kaufman PL. Effects of adenosine agonists on intraocular pressure and aqueous humor dynamics in cynomolgus monkeys. Exp Eye Res. 1997;64(6):979-989.

59. Fleischhauer JC, Mitchell CH, Stamer WD, Karl MO, Peterson-Yantorno K, Civan MM. Common actions of adenosine receptor agonists in modulating human trabecular meshwork cell transport. J Membr Biol. 2003;193(2):121-136.
60. Crosson CE, Sloan CF, Yates PW. Modulation of conventional outflow facility by the adenosine $\mathrm{A}_{1}$ agonist $\mathrm{N}^{6}$-cyclohexyladenosine. Invest Ophthalmol Vis Sci. 2005;46(10):3795-3799.

61. Husain S, Shearer TW, Crosson CE. Mechanisms linking adenosine $A_{1}$ receptors and extracellular signal-regulated kinase 1/2 activation in human trabecular meshwork cells. J Pharmacol Exp Ther. 2007;320(1): 258-265.

62. Karl MO, Peterson-Yantorno K, Civan MM. Cell-specific differential modulation of human trabecular meshwork cells by selective adenosine receptor agonists. Exp Eye Res. 2007;84(1):126-134.

63. Mitchell CH, Peterson-Yantorno K, Carré DA, et al. $\mathrm{A}_{3}$ adenosine receptors regulate $\mathrm{Cl}$ - channels of nonpigmented ciliary epithelial cells. Am J Physiol. 1999;276(3):C659-C666.

64. Do CW, Civan MM. Swelling-activated chloride channels in aqueous humour formation: on the one side and the other. Acta Physiol. 2006;187(1-2):345-352.

65. Kim N, Crosson C, Supuran C, et al. INO-8875, an adenosine $\mathrm{A}_{1}$ agonist, in development for open-angle glaucoma reduces IOP in three rabbit models. Invest Ophthalmol Vis Sci. 2009;50: ARVO E-Abstract 4061.

66. Kim N, Crosson C, Lam T, et al. INO-8875, an adenosine $\mathrm{A}_{1}$ agonist, lowers intraocular pressure through the conventional outflow pathway. Invest Ophthalmol Vis Sci. 2010;51: ARVO E-Abstract 3238.

67. Webb RL, Sills MA, Chovan JP, Peppard JV, Francis JE. Development of tolerance to the antihypertensive effects of highly selective adenosine $\mathrm{A}_{2 \mathrm{a}}$ agonists upon chronic administration. $J$ Pharmacol Exp Ther. 1993;267(1):287-295.

68. Klinger M, Freissmuth M, Nanoff C. Adenosine receptors: G proteinmediated signalling and the role of accessory proteins. Cell Signal. 2002;14(2):99-108.

69. Jacobson KA, Gao ZG. Adenosine receptors as therapeutic targets. Nat Rev Drug Discov. 2006;5(3):247-264.

70. Avni I, Garzozi HJ, Barequet IS, et al. Treatment of dry eye syndrome with orally administered CF101: data from a Phase 2 clinical trial. Ophthalmology. 2010;117(7):1287-1293.

71. Gessi S, Merighi S, Varani K, Leung E, Mac Lennan S, Borea PA. The $\mathrm{A}_{3}$ adenosine receptor: an enigmatic player in cell biology. Pharmacol Ther. 2008;117(1):123-140.

72. Okamura T, Kurogi Y, Hashimoto K, et al. Structure-activity relationships of adenosine $\mathrm{A}_{3}$ receptor ligands: new potential therapy for the treatment of glaucoma. Bioorg Med Chem Lett. 2004;14(14): 3775-3779.

73. Vaajanen A, Luhtala S, Oksala O, Vapaatalo H. Does the renin-angiotensin system also regulate intra-ocular pressure? Ann Med. 2008;40(6): 418-427.

74. Fletcher EL, Phipps JA, Ward MM, Vessey KA, Wilkinson-Berka JL. The renin-angiotensin system in retinal health and disease: Its influence on neurons, glia and the vasculature. Prog Retin Eye Res. 2010;29(4): 284-311.

75. Rao PV, Deng P, Sasaki Y, Epstein DL. Regulation of myosin light chain phosphorylation in the trabecular meshwork: role in aqueous humour outflow facility. Exp Eye Res. 2005;80(2):197-206.

76. Cullinane AB, Leung PS, Ortego J, Coca-Prados M, Harvey BJ. Renin-angiotensin system expression and secretory function in cultured human ciliary body non-pigmented epithelium. $\mathrm{Br} J$ Ophthalmol. 2002;86(6):676-683.

77. Wang RF, Podos SM, Mittag TW, Yokoyoma T. Effect of CS-088, an angiotensin $\mathrm{AT}_{1}$ receptor antagonist, on intraocular pressure in glaucomatous monkey eyes. Exp Eye Res. 2005;80(5):629-632.

78. Stapp L, Fan S, Toris CB. The effects of the angiotensin II receptor antagonist, olmesartan, on aqueous humor dynamics in monkeys. Invest Ophthalmol Vis Sci. 2008;49: ARVO E-Abstract 353.

79. Tomida I, Pertwee RG, Azuara-Blanco A. Cannabinoids and glaucoma. Br J Ophthalmol. 2004;88(5):708-713.

80. Pacher P, Bátkai S, Kunos G. The endocannabinoid system as an emerging target of pharmacotherapy. Pharmacol Rev. 2006;58(3):389-462.

81. Russo EB. History of cannabis and its preparations in saga, science, and sobriquet. Chem Biodivers. 2007;4(8):1614-1648. 
82. Chien FY, Wang RF, Mittag TW, Podos SM. Effect of WIN 55212-2, a cannabinoid receptor agonist, on aqueous humor dynamics in monkeys. Arch Ophthalmol. 2003;121(1):87-90.

83. Yao BB, Hsieh GC, Frost JM, et al. In vitro and in vivo characterization of A-796260: a selective cannabinoid $\mathrm{CB}_{2}$ receptor agonist exhibiting analgesic activity in rodent pain models. Br J Pharmacol. 2008;153(2): 390-401.

84. Stamer WD, Golightly SF, Hosohata Y, et al. Cannabinoid $\mathrm{CB}_{1}$ receptor expression, activation and detection of endogenous ligand in trabecular meshwork and ciliary process tissues. Eur J Pharmacol. 2001;431(3): 277-286.

85. Stumpff F, Boxberger M, Krauss A, et al. Stimulation of cannabinoid $\mathrm{CB}_{1}$ and prostanoid $\mathrm{EP}_{2}$ receptors opens $\mathrm{BKCa}$ channels and relaxes ocular trabecular meshwork. Exp Eye Res. 2005;80(5): 697-708.

86. Ramer R, Hinz B. Cyclooxygenase-2 and tissue inhibitor of matrix metalloproteinases- 1 confer the antimigratory effect of cannabinoids on human trabecular meshwork cells. Biochem Pharmacol. 2010;80(6): 846-857.

87. McCallister E, Bernstein K. The eyes have it. BioCentury, The Bernstein Report on BioBusiness, 2008 Sept 29;page 1 of 8. http://www.biocentury.com.

88. Gagliano C, Longo A, Ortisi E, et al. Ocular hypotensive efficacy and safety of oral palmytoilethanolamide (Visimast ${ }^{\circledR}$ ): clinical study. Invest Ophthalmol Vis Sci. 2010;51: ARVO E-Abstract 988.
89. Nichols DE, Nichols CD. Serotonin receptors. Chem Rev. 2008;108(5) 1614-1641.

90. Costagliola C, Parmeggiani F, Semeraro F, Sebastiani A. Selective serotonin reuptake inhibitors: a review of its effects on intraocular pressure. Curr Neuropharmacol. 2008;6(4):293-310.

91. Gabelt BT, Millar CJ, Kiland JA, Peterson JA, Seeman JL, Kaufman PL. Effects of serotonergic compounds on aqueous humor dynamics in monkeys. Curr Eye Res. 2001;23(2):120-127.

92. May JA, McLaughlin MA, Sharif NA, Hellberg MR, Dean TR. Evaluation of the ocular hypotensive response of serotonin 5-HT $\mathrm{HA}_{1 \mathrm{~A}}$ and $5-\mathrm{HT}_{2}$ receptor ligands in conscious ocular hypertensive cynomolgus monkeys. J Pharmacol Exp Ther. 2003;306(1):301-309.

93. Gabelt BT, Okka M, Dean TR, Kaufman PL. Aqueous humor dynamics in monkeys after topical R-DOI. Invest Ophthalmol Vis Sci. 2005;46(12):4691-4696.

94. Allen JA, Yadav PN, Roth BL. Insights into the regulation of $5-\mathrm{HT}_{2 \mathrm{~A}}$ serotonin receptors by scaffolding proteins and kinases. Neuropharmacology. 2008;55(6):961-968.

95. Gray JA, Roth BL. Paradoxical trafficking and regulation of 5- $\mathrm{HT}_{2 \mathrm{~A}}$ receptors by agonists and antagonists. Brain Res Bull. 2001;56(5): 441-451.

96. Bunch TJ, Seeman JL, Gabelt BT, et al. BVT.28949 as a potential ocular hypotensive agent in monkeys. Invest Ophthalmol Vis Sci. 2004;45: ARVO E-Abstract 5040
Clinical Ophthalmology

\section{Publish your work in this journal}

Clinical Ophthalmology is an international, peer-reviewed journal covering all subspecialties within ophthalmology. Key topics include: Optometry; Visual science; Pharmacology and drug therapy in eye diseases; Basic Sciences; Primary and Secondary eye care; Patien Safety and Quality of Care Improvements. This journal is indexed on

\section{Dovepress}

PubMed Central and CAS, and is the official journal of The Society of Clinical Ophthalmology (SCO). The manuscript management system is completely online and includes a very quick and fair peer-review system, which is all easy to use. Visit http://www.dovepress.com/ testimonials.php to read real quotes from published authors. 